\title{
Effects of nutrition on sexual ornaments and humoral immune responsiveness in adult male pheasants
}

\author{
T. Ohlsson ${ }^{1}$, H.G. SMith, L. RÅBerg and D. Hasselquist \\ Department of Animal Ecology, Lund University, S-223 62 Lund, Sweden
}

Received 23 January 2002, accepted 18 December 2002

Female pheasants may base their choice of mates on the expression of male ornaments such as the red chin wattle and the length of the spurs. Both these ornaments are predicted to be sensitive to access to carotenoids (and vitamins). Moreover, because carotenoids also enhance immune function, it has been suggested that there is a trade-off in the use of carotenoids for ornament expression and immune function. We fed adult male ring-necked pheasants (Phasianus colchicus) with food of different nutritional quality. This relieved males from restrictions of access to dietary carotenoids and allowed us to study the simultaneous effect on ornament expression (wattle size and redness, spur length) and immune responsiveness. Two treatment groups were given either a low or a high quality fodder between late February and late May, when males were 8-11 months old. As a result of the food-quality manipulation, males in the high nutrient group achieved significantly redder wattles whereas no significant effect was found for either wattle size or spur length. There was a non-significant tendency that the antibody response to one out of two novel antigens was affected by the experimental treatment, but the mean production of antibodies against the two antigens (diphtheria and tetanus toxoid) was not significantly related to the experimental treatments. Over the experimental period, the change in humoral immune responsiveness was positively related to the increase in spur length, but not related to the change in wattle colouration. We suggest that wattle colour may be an honest indicator of males' ability to find or assimilate dietary carotenoids, but we found no firm evidence that the mechanism maintaining honesty is a trade-off between the use of carotenoids for ornament colouration and general immune function. In contrast, our study lends some support to the idea that spur length, a sexually selected trait, may reflect humoral immunocompetence in male pheasants.

KEY WORDS: sexual selection, male ornaments, carotenoids, colour, immunocompetence, ELISA, Phasianus colchicus.

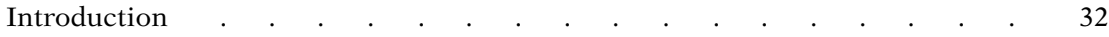

Methods . . . . . . . . . . . . . . . . . . . . . . . 33

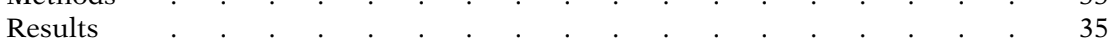

\footnotetext{
${ }^{1}$ Corresponding author: Thomas Ohlsson (E-mail: thomas.ohlsson@zooekol.lu.se).
} 


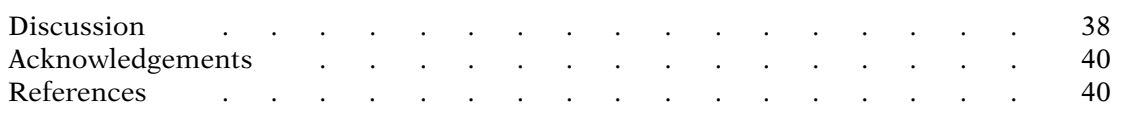

\section{INTRODUCTION}

Females often base their choice of mates on the expression, size, or colourintensity of male sexual ornaments, and it has been suggested that females with such preferences obtain good genes for their offspring (ANDERSSON 1994). To be a reliable signal of good genes, these traits must reveal something about the bearers' quality (e.g. ZAHAVI 1975, 1977; GRAFEN 1990; IWASA et al. 1991).

Nutritional constraints have been shown to affect the expression of various sexual traits in several taxa, i.e. the size of the breast badge in house sparrows, Passer domesticus (VEIGA \& PUERTA 1996), carotenoid colouration in guppies, Poecilia reticulata (KODRIC-BROWN 1989), song rate in pied flycatchers, Ficedula hypoleuca (GotTLANDER 1987), and song repertoire size in great reed warblers, Acrocephalus arundinaceus (Nowicki et al. 2000). If the expression of male sexual ornaments is affected by nutrition, the ornament is condition-dependent and may signal both phenotypic and genotypic quality.

The bright yellow, orange and red colours commonly found in the combs, wattles, beaks, skin patches, eyes and feathers in birds are in most cases caused by carotenoid pigmentation (RALPH 1969). In several bird species, these carotenoidbased colours function as ornaments and are used by females when selecting mates (e.g. Burley \& Coopersmith 1987, Hill 1990). For example, red skin-wattles have been shown to function as ornaments in black grouse, Tetrao tetrix (RINTAMäKI et al. 2000). Carotenoids cannot be synthesised by vertebrates and must therefore be ingested via the diet (e.g. BRUSH 1978). In birds, carotenoid pigmentation may signal individual condition (e.g. HiLl \& Montgomerie 1994, Hill 1996). Theory predicts that individuals in good condition express more elaborate ornaments, and carotenoid-based pigmentation has been shown to be negatively affected by parasitic infection (reviewed by Hill 1999, BraWner et al. 2000, McGraW \& Hill 2000, Hatchwell et al. 2001). Thus, carotenoid pigmentation of sexual ornaments may function as a reliable signal of individual condition.

In Swedish pheasants, it has been shown that males with longer spurs gain larger harems and have higher viability (vON SCHANTZ et al. 1989, GöRANSSON et al. 1990), and they sire more offspring that survive better (vON SCHANTZ et al. 1994). Moreover, males with certain MHC haplotypes, a highly variable gene complex that is important for immune function as it underlies recognition of pathogens, had longer spurs and higher survival, suggesting that spur length may reflect both viability and immune function (vON ScHANTZ et al. 1996). It has been argued that there are reasons to believe that both spur length and immune function are sensitive to oxidative stress, and thus also to access to antioxidants such as carotenoids and vitamins (vON SCHANTZ et al. 1999). Hence, spur length could be an ornament that is reflecting the carotenoid (and vitamin) content of the diet.

Several hypotheses have proposed that the expression of ornaments reliably signals a heritable resistance capability of the immune system (HAMILTON \& ZUK 1982, FOLSTAD \& KARTER 1992). The resistance to parasites and pathogens may either be pathogen-specific or a result of a generally better immune function (WESTNEAT \& BIRKHEAD 1998). There is evidence that dietary stress can have negative effects on immune function in birds. Different amounts of food (KLASING 1988, SAINo et al. 
1997), protein content (LochmiLLER et al. 1993) or micronutrients such as vitamins (KLASING 1998) have been shown to affect immune responsiveness and/or the ability to handle infections. For example, vitamin-A deficiency during embryonic growth resulted in impaired resistance to several diseases among broiler chicks (SKLAN et al. 1994). It has been suggested that carotenoids may have a dual function in affecting ornament expression and serving an important role for body maintenance, such as antioxidant defence and immune function (e.g. LozANo 1994, 2001; vON SCHANTZ et al. 1999). Thus, males having a high uptake of carotenoids may therefore be able to grow both elaborate ornaments and have an efficient immune system.

The ring-necked pheasant is a sexually dimorphic species, with males being larger and extensively ornamented compared to the cryptic females. The males' various ornaments are used in both intra- and inter-sexual selection (reviewed in Mateos 1998). Pheasants have a socially polygynous mating system and males do not participate in the rearing of young. In a Swedish population of pheasants, spur length was the most important trait for female mate choice, with a female preference for long-spurred individuals among after-second-year old (ASY) males (vON SCHANTZ et al. 1989, GörANSSON et al. 1990). In a study of pheasants in Spain, the length of male spurs was correlated to physical condition [in second year (SY) males] and dominance (in ASY), however there was no female preference for longspurred males (Mateos \& CARRANZa 1996). Instead, female choice seemed to be based on characteristics of the wattle as well as the length of ear tufts and tail feathers (MATEOS \& CARRANZA 1995). In a study of English pheasants, the brightness of the wattle was important for female choice (HillgarTh \& WingFIELD 1997). The red wattle in male pheasants is a striking character that can be engorged and is used during courtship as well as in dominance behaviour between males (TABER 1949, Mateos 1998, T. OHLSSON pers. obs.).

In this study we conducted a food-quality manipulation experiment on captive ring-necked pheasants during the early breeding season (February to May, 2000). The birds used in the study were all born the previous year, hence they were 8-11 months old during the experiment. The aim was to investigate if differences in the nutritive value of food during the early breeding period affected the expression of male ornaments and immune function. In particular, we wanted to investigate if nutritional condition had similar effects on these two traits, which would suggest that ornaments could honestly reflect immune function. The experimental setup tried to mimic a situation where the males held territories of different food quality, a situation where males differed in their ability to find high quality food, or where males were differentially able to handle variation in nutrient availability.

\section{METHODS}

\section{Experimental setup and housing}

The pheasants in this study were hatched in the summer of 1999 and raised and reared together. To investigate if variation in food quality can affect the expression of the ornaments in adult males during the early part of the breeding season, 32 male pheasants were randomly assigned to one of two different food treatments. The pheasants received either a high quality food consisting of commercial chicken fodder, Allfoder veg ${ }^{\circledR}$ (Skånska Lantmännen. Malmö, Sweden) or a low quality food consisting of whole-wheat grains. The experiment was started on February 27, and ended on May 28, 2000. 
Prior to the experiment, pheasants were housed in an $80 \mathrm{~m}^{2}$ outdoor aviary, divided into two compartments of equal size and appearance. In each compartment there was a small room where the birds could seek shelter in case of inclement weather. At the onset of the experiment, the birds were randomly divided into two treatment groups, each containing 16 males. The two groups were then kept apart from each other. To avoid competition between the pheasants, both water and food were available ad libitum and provided at several feeders in each compartment throughout the entire experiment. A comparison of the nutrient contents in Allfoder veg ${ }^{\circledR}$ and whole-wheat grains shows that Allfoder veg ${ }^{\circledR}$ is richer in most nutrients. However, the main difference is the higher content of carotenoids in Allfoder veg ${ }^{\circledR}$ compared to whole-wheat grain (Table 1). After some accidental escapes and mortality, the experimental groups finally consisted of nine males in the high and ten males in the low fodder group.

\section{Measurements of ornament size and colour}

At the onset of the experiment, all birds were weighed to the nearest $0.1 \mathrm{~g}$ on a digital balance (Mettler Toledo ${ }^{\circledR}$ ) and their ornaments were measured. Spurs length was measured from the tip to the distal edge of the tarsus. From this measurement we then subtracted the thickness of the tarsus to obtain a measure of the actual length of the spur. The wattles were photographed with a digital camera (Fuji DX-7). Included on each photo was a ruler to facilitate calibration. The height of the left and right wattle was measured to the nearest $0.1 \mathrm{~mm}$ from digital photos on the computer screen using graphical software, Adobe PhotoShop ${ }^{\circledR}$ (AdobE Systems INC. 1998). In some cases the head of the bird was not placed exactly horizontal and therefore could not be measured accurately; in such cases no measurements were taken. The area and the height of the wattle are highly correlated in pheasants (BRIGANTI et al. 1999). Thus, we have used the height (vertical axis) of the wattle as the measure of wattle size. We measured the colour of the

\section{Table 1.}

A comparison of the nutritional contents of Allfoder veg ${ }^{\circledR}$ and whole wheat-grains. (Data from SKÅNSKa LANTMÄNNEN, Malmö, Sweden; Olsson 1954, ERIKSSON et al. 1972).

\begin{tabular}{lcc}
\hline Contents & Allfoder veg ${ }^{\circledR}$ & Wheat \\
\hline Protein $(\%)$ & 16.0 & 13.0 \\
Fat $(\%)$ & 5.5 & 2.5 \\
Fibre (\%) & 5.0 & 2.5 \\
Ash (\%) & 11.0 & 2.0 \\
\hline Metionine $(\mathrm{g} / \mathrm{kg})$ & 4.0 & 1.8 \\
Lysine $(\mathrm{g} / \mathrm{kg})$ & 7.2 & 2.6 \\
Ca $(\mathrm{g} / \mathrm{kg})$ & 1.3 & 0.6 \\
P $(\mathrm{g} / \mathrm{kg})$ & 0.6 & 3.4 \\
\hline Energy $(\mathrm{MJ} / \mathrm{kg})$ & 11.2 & - \\
Vitamin A $(\mathrm{MJ} / \mathrm{kg})$ & 12000 & - \\
Vitamin $\mathrm{D}_{3}(\mathrm{MJ} / \mathrm{kg})$ & 3000 & - \\
Vitamin E $(\mathrm{MJ} / \mathrm{kg})$ & 70 & 4.0 \\
Cu $(\mathrm{mg} / \mathrm{kg})$ & 7.0 & - \\
Selene $(\mathrm{mg} / \mathrm{kg})$ & 0.3 & 0.1 \\
Carotene $(\mathrm{mg} / \mathrm{kg})$ & 4.1 & \\
\hline
\end{tabular}


wattles using a colorimeter (Colortron II, LIGHT SouRcE 1994). We took three measures on each wattle, in total six measures on each bird, and excluded the two extremes before we calculated mean values of hue, saturation and brightness using the Colortron software. In all, four measurements were used to create the mean values of hue, saturation and brightness for each pheasant. The overall colour score for each pheasant was then calculated as the first principal components score of these measures (HILL 1998). We always measured colour at the same spot on the wattle in all pheasants (above the eye). At the end of the experiment the birds were measured again using the same methods. All measurements were taken by the same person (T. OHLSSON).

\section{Immunisation and ELISA assay}

We measured humoral immune responsiveness as the antibody production to two nonpathogenic antigens. All birds were first vaccinated in December 1999 (i.e. before the start of the experiment) and then again at the end of the experiment in May 2000. The antibody responses to these vaccinations are referred to as primary and secondary responses, respectively. On each occasion birds were immunised with $140 \mu \mathrm{l}$ diphtheria-tetanus vaccine (SBL, Stockholm, Sweden) intramuscularly in the pectoral muscle. This vaccine contains two different protein antigens, diphtheria and tetanus toxoid, hence, we obtained two measures of humoral immune responsiveness. Blood samples (ca $300 \mu$ l, taken from the wing vein) were collected in tubes with heparin and stored on ice until centrifugation (3000 rpm for $7 \mathrm{~min}$ ) later the same day, and the plasma was then extracted and stored at $-20{ }^{\circ} \mathrm{C}$ until later analysis. Antibody titers were analysed using an enzyme-linked immunosorbent assay, ELISA (see SVENSSON et al. 1998; Hasselquist et al. 1999, 2001; OHLsson et al. 2002). High binding 96well plates (Costar) were coated overnight with either diphtheria toxoid or tetanus toxoid (3 $\mu \mathrm{g} / \mathrm{ml}$ in $0.15 \mathrm{M}$ carbonate buffer, $\mathrm{pH}$ 9.6). After three washings in PBS/Tween 20 (0.01 M PBS with $0.05 \%$ Tween 20), wells were blocked with 3\% milk powder in PBS/Tween 20 for 2 $\mathrm{hr}$ at room temperature. After two washings, dilutions of plasma (1:1000 for primary responses and 1:3000 for secondary responses, in PBS/Tween 20 with 1\% milk powder) were added in duplicates and plates were then incubated overnight at $4{ }^{\circ} \mathrm{C}$. The following day, plates were washed three times and thereafter incubated for $45 \mathrm{~min}$ at $37{ }^{\circ} \mathrm{C}$ with a peroxidase-conjugated rabbit-anti-chicken IgG antibody diluted 1:10000 (Cat. A9792, Sigma). Finally, plates were washed 2 times and colour reaction was achieved by the addition of $200 \mu \mathrm{l} 0.2 \mathrm{mM}$ ABTS (2,2-azino-bis-3-ethylbenzthiazoline-6-sulfonic acid, Cat. A1888, Sigma) and $80 \mu \mathrm{H} \mathrm{H}_{2} \mathrm{O}_{2}(30 \%$ $\mathrm{H}_{2} \mathrm{O}_{2}$ diluted 1:50 in dd $\mathrm{H}_{2} \mathrm{O}$ ), mixed in $20 \mathrm{ml}$ citrate buffer ( $\mathrm{pH} 4.0$ ). Kinetics of colour reactions were measured by reading plates every $30 \mathrm{sec}$ for $14 \mathrm{~min}$ using a Vmax, MAXline microplate reader (Molecular Devices, Sunnyvale, USA). Antibody titers were obtained as the slope of the substrate conversion over time in the unit $10^{-3} \times$ Optical Density/min (mOD/min). To be able to compare ab-titers of samples run on different plates, we run a serially diluted standard (pooled serum from pheasants with very high antibody titres to diphtheria and tetanus toxoid), on all plates. This made it possible to recalculate the $\mathrm{mOD} / \mathrm{min}$ value of each sample to a common "ab-titer unit" that facilitated comparison between plates.

Statistics were performed using SYSTAT (WILKINSON 1987). All probability distributions are two-tailed, and we present mean \pm SE. All values for diphtheria and tetanus antibody titers were log transformed to achieve normality.

\section{RESULTS}

\section{Nutritional effects on ornament quality}

Males in the high nutrient group showed an increase in wattle redness $(-0.02$ to 0.75 ; paired t-test: $\mathrm{t}=2.53, \mathrm{df}=8, P=0.035$ ), whereas males in the low nutrient 
group decreased in wattle redness $(-0.31$ to -0.84$)$, but not significantly so (paired t-test: $\mathrm{t}=-1.61, \mathrm{df}=9, P=0.14)$. Thus, the experimental treatment had a significant effect on the change in wattle colour score (ANCOVA, the effect of treatment when controlling for original colour score: $F_{1,16}=26.56, P=0.0001$; Fig. 1a). Because there was no initial difference in redness between treatments at the onset of the experiment (ANOVA: $F_{1,17}=0.55, P=0.47$ ), this resulted in males in the high nutrient treatment having redder wattles after the experiment than males in the low nutrient group (ANOVA, $\mathrm{F}_{1,17}=29.67, P=0.0001$ ).

Wattle size increased in both the high and the low nutrient groups $(0.58 \pm$ 0.25 and $0.47 \pm 0.37 \mathrm{~mm}$ respectively; Fig. 1b). However, the difference between treatments was not significant (ANCOVA wattle size between treatments after the experiment, controlling for original size: $\mathrm{F}_{1,16}=0.87, P=0.36$ ).

The spurs of males in the high nutrition group grew on average more than those in the low nutrition group $(1.27 \pm 0.66$ and $0.76 \pm 0.93 \mathrm{~mm}$, respectively; Fig. 1c), but this difference was not significant (ANCOVA, spur length between treatments after the experiment, controlling for original length: $F_{1,15}=0.18, P=0.68$ ).

All birds lost body mass during the experimental period and those fed the low nutrition diet lost most mass $(-84.4 \pm 53.3$ and $-117.9 \pm 53.4$ g respectively; Fig.
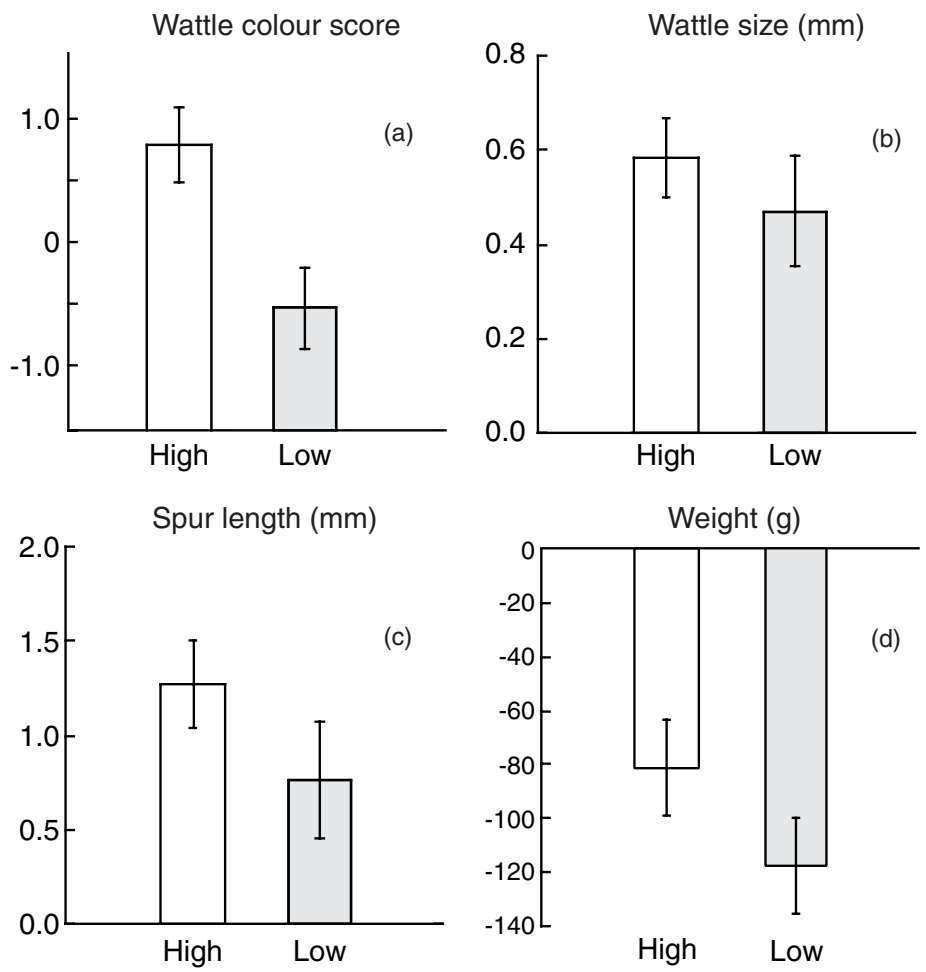

Fig. 1. - The change in the expression of (a) wattle colour, (b) wattle size, (c) spur length, and (d) body mass between treatments $( \pm \mathrm{SE})$. Values represent the post-experimental minus the pre-experimental measures. 
1d), but this difference was not significant (ANCOVA, mass between treatments after the experiment, controlling for original mass: $\mathrm{F}_{1,15}=1.25, P=0.28$ ). There was no difference between experimental groups in mass when controlling for tarsus length $\left(F_{1,31}=0.54, P>0.47\right)$, suggesting that the treatment had no effect on male condition.

\section{Nutrition and antibody responsiveness}

All animals mounted an antibody response against both the diphtheria and tetanus antigens. The antibody titers against diphtheria and tetanus toxoid were significantly positively correlated to each other (Pearson correlations, primary responses, $\mathrm{r}=0.81, \mathrm{df}=15, P=0.0001$; secondary responses, $\mathrm{r}=0.86, \mathrm{df}=15, P=$ $0.0001)$. To obtain a common measure of immunological capacity, we calculated the average of the residuals from the regressions of secondary responses on primary responses for the two antibody titres.

There was a non-significant tendency for the nutrient manipulation to affect the production of antibodies with the birds receiving the high nutrient treatment having a higher residual production of antibodies (ANOVA: $\mathrm{F}_{1,15}=2.64, P=0.12$ ). The residual antibody production actually increased in the high nutrition group $(0.36 \pm 0.50)$, compared to the low nutrition group where the production decreased $(-0.40 \pm 1.31)$. Considering the two antigens separately, there was a non-significant tendency for antibody titres against diphtheria toxoid to be higher in the high than in the low nutrient group (ANCOVA: the effect of the treatment when controlling for initial antibody titre, $F_{1,14}=4.02, P=0.065$ ), whereas there was no significant difference regarding the production of antibodies against tetanus toxoid (ANCOVA, $\left.\mathrm{F}_{1,14}=0.95, P=0.35\right)$.

\section{Ornament size and immunity}

To investigate if there was a change in humoral responsiveness in relation to the change in ornament expression during the experiment, we related the residual

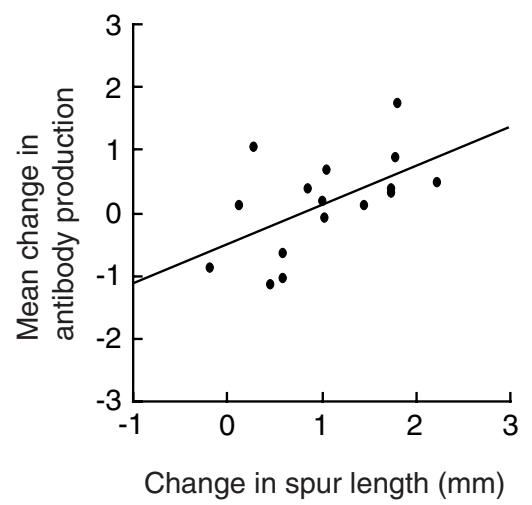

Fig. 2. - The change in spur length in relation to the change in antibody production over the course of the nutrition experiment. Values represent post- minus pre-experimental measures. 
production of antibodies (see above) to the residual change in ornament colouration/size. We found that the growth in spur length during the experiment was significantly positively correlated with the change in mean antibody production during the same period $(r=0.58, \mathrm{df}=13, P=0.024$, Fig. 2$)$. Neither the residual change in wattle size or wattle colour was related to the change in antibody production (wattle colour: $\mathrm{r}=0.16$, $\mathrm{df}=15, P=0.54$; wattle size: $\mathrm{r}=-0.13$, $\mathrm{df}=15, P=$ $0.61)$. Also when considering the two antigens separately there was no significant relationship to the change in wattle colour (diphtheria: $\mathrm{r}=0.30, \mathrm{df}=15, P=0.25$; tetanus: $\mathrm{r}=-0.04, \mathrm{df}=15, P=0.88$ ) or wattle size (diphtheria: $\mathrm{r}=-0.08, \mathrm{df}=15, P$ $=0.77$; tetanus: $\mathrm{r}=-0.19, \mathrm{df}=15, P=0.77)$, whereas for spur length the production of antibodies against diphtheria $(\mathrm{r}=0.60 \mathrm{df}=13, P=0.017)$, but not against tetanus $(\mathrm{r}=0.46, \mathrm{df}=13, P=0.086)$, were significant.

\section{DISCUSSION}

The experimental treatment affected the intensity of the red colouration of the wattles. In contrast, although the spurs were growing during the experiment, there was no significant difference between the experimental treatments in growth rate. It seems likely that the general difference in nutritive value between the two treatments was too small to have a significant effect on spur and wattle growth over the relatively short time span (2.5 months) of the experiment. The absence of a significant difference in mass-change between the experimental groups support this view that the nutrition manipulation was small. The most likely explanation for the difference in colour change between the experimental groups is the difference in carotenoid content between the food treatments. Thus, this result corroborates earlier studies demonstrating that the colouration of carotenoid-based ornaments is restricted by the dietary intake of carotenoids (e.g. Hill 1992, Hill et al. 1994).

An important issue is why females base their choice of mates on expression of ornaments affected by access to carotenoids. For a signal to reveal reliable information about the bearer's quality, it has to be costly (ZAHAVI 1975, 1977; GRAFEN 1990). It has been suggested that depositing carotenoids in ornaments is costly, because there is limited availability of carotenoids in the diet of many animals (ENDLER 1980, Kodric-Brown 1989, Hill 1990). The present experiment is compatible with this explanation. Thus, a well-ornamented male may be one with a superior foraging ability or ability to assimilate carotenoids from the diet. By selecting such a male, females may gain either direct benefits (guarding by the male during egg-formation or breeding in a superior territory) or indirect benefits (more viable offspring) (cf. GöransSON \& LOMAN 1986, RidLey \& Hill 1987, von SchantZ et al. 1989).

If the expression of carotenoid-based ornaments is limited by the availability of carotenoids in the diet, any process that either affects the assimilation or the use of carotenoids may secondarily affect the colour of the ornaments. For example, parasites may compromise carotenoid intake or expression, and the ornament therefore reveals heritable resistance to these parasites (cf. RUFF et al. 1974, HoudE \& TORIO 1992, BRAWNER et al. 2000). Recently it has been suggested that carotenoids play an important role for immune function (review in BENDICH 1989). Thus, a male with a superior immune defence could allocate more carotenoids to ornaments (SHYKofF \& WIDMER 1996). If the above reasoning were true, males given additional carotenoids should be able to shunt more carotenoids both to 
ornaments and to immune defence (LozANo 1994, von Schantz et al. 1999). However, we found no consistent effect of the experimental treatment on the production of antibodies against diphtheria and tetanus. There was a non-significant trend that the former was affected by the treatment, but there was no significant effect when considering the mean production of the two antigens. In addition, the change in wattle colour was unrelated to the humoral immune responsiveness to the two antigens. This result is in line with a recent review by HiLL (1999) questioning that differential access to carotenoids can explain differences in immunocompetence in birds. However, the sample size in our experiment is rather low and only one aspect of the immune defence system (humoral immune responsiveness) was measured, so this question calls for further studies.

According to the immunocompetence handicap hypothesis, testosteronedependent ornaments should remain honest signals of male quality because testosterone also has a negative effect on immune function (FOLSTAD \& KARTER 1992). In some recent studies on male pheasants, a positive relationship between plasma testosterone levels and wattle size has been found (BRIGANTI et al. 1999, PAPESCHI et al. 2000). Hence, it is possible that a higher level of circulating testosterone in males with larger (and redder) wattles has suppressed humoral immune responsiveness, which would explain the lack of relationships between wattle size and colour and humoral immune function. This, however, needs to be investigated in more detail in subsequent studies.

Nutritional constraints on the capacity of the immune system have been found in several studies, e.g. amount of food (KLASING 1988, SAINo et al. 1997), amount of protein (LOCHMILLER et al. 1993), amount of vitamin A (SKLAN et al. 1994), and amount of vitamin E (BoA-AMPONSEM et al. 2000). In our study, the high nutrient treatment contained higher levels of most nutrients, including vitamin A and E, as compared with the low treatment. However, although there was a weak effect on the production of antibodies against diphtheria, these differences in food constitution did not significantly affect the mean production of antibodies against diphtheria and tetanus toxoid. Our experiment did not affect the condition of the birds significantly, as measured by humoral immune responsiveness and sizeadjusted mass. Still, however, there seemed to be differences between birds in condition as shown by the co-variation between the change in immune responsiveness and spur growth within experimental groups (Fig. 2). This intra-treatment variation may e.g. be related to dominance hierarchies between males, different levels of parasitic infections or some other differences in quality between males. In another study, the growth of the spur seemed to be sensitive to dietary differences (KOUBEK \& HRABE 1984). This suggests that spur length may reliably reflect at least one important aspect of immunocompetence in these birds. This is in line with earlier findings that the strength of the cell-mediated immune defence was related to spur length in pheasants (OHLSson et al. 2002), and that males with certain MHC haplotypes had longer spurs and higher survival (VON SCHANTz et al. 1996).

In conclusion, we have demonstrated that wattle colour is affected by the nutritive value of the food, most likely through access to dietary carotenoids. Wattle colour may be an honest ornament because it reflects ability to ingest dietary carotenoids or to minimise alternative physiological uses of carotenoids. We did not, however, find consistent evidence that the mechanism maintaining honesty is a trade-off between the use of carotenoids for ornament colouration and general immune function. However, a firm conclusion requires additional studies where other aspects of the immune system are measured. In contrast, our study lends 
support to the idea that spur length, a sexually selected trait (von ScHANTz et al. 1989), may reflect humoral immunocompetence in adult male pheasants.

\section{ACKNOWLEDGEMENTS}

This study was supported by grants from Kungliga Vetenskapsakademien (Hierta Retzius), Kungliga Fysiografiska sällskapet i Lund, Stiftelsen MB, P.O. Lundells fond för jordbruksstudier and Lunds Djurskyddsfond (to T. Ohlsson). Crafoordska stiftelsen (to T. Ohlsson and D. Hasselquist), Carl Tryggers stiftelse (to D. Hasselquist), and the Swedish Council for Environment, Agriculture and Spatial Planning (to H.G. Smith and D. Hasselquist). This study was approved by the ethical committee for animal research, Malmö/Lund, Sweden. We thank Geoff Hill and two anonymous referees for valuable comments on an earlier version of the manuscript.

\section{REFERENCES}

Adobe Systems Inc. 1998. Adobe Photoshop 5.0. San José, California, USA.

Andersson M. 1994. Sexual selection. Princeton: Princeton University Press.

BENDICH A. 1989. Carotenoids and the immune response. Journal of Nutrition 119: 112-115.

Boa-Amponsem K., Price S.E.H., Picard M., Geraert P.A. \& Siegel P.B. 2000. Vitamin E and immune responses of broiler pureline chickens. Poultry Science 79: 466-470.

Brawner III W.R., Hill G.E. \& Sundermann C.A. 2000. Effects of coccidial mycoplasmal infections on carotenoid-based plumage pigmentation in male house finches. Auk 117: 952-963.

Briganti F., Papeschi A., Mugnai T. \& Dessì-Fulgheri F. 1999. Effect of testosterone on male traits and behaviour in juvenile pheasants. Ethology Ecology \& Evolution 11: 171-178.

BRush A.H. 1978. Avian pigmentation, pp. 141-164. In: Brush A.H., Edit. Chemical zoology, Vol. X. Aves. New York: Academic Press.

Burley N. \& Coopersmith C.B. 1987. Bill color preferences of Zebra finches. Ethology 76: 133-151.

ENDLER J.A. 1980. Natural selection on color patterns in Poecilia reticulata. Evolution 34: 76-91.

ERIKSSON S., SANNE S. \& ThOMKE S. 1972. Fodermedlen - sammansättning, näringsvärde, användbarhet. Borås: LTs Förlag.

Folstad I. \& KARTER A.J. 1992. Parasites, bright males, and the immunocompetence handicap. The American Naturalist 139: 603-622.

GotTLANDER K. 1987. Variation in the song rate of the male pied flycatcher Ficedula hypoleuca: causes and consequences. Animal Behaviour 35: 1037-1043.

GRAFEN A. 1990. Biological signals as handicaps. Journal of Theoretical Biology 144: 517-546.

Göransson G. \& Loman J. 1986. Predation and habitat distribution of pheasant (Phasianus colchicus) nests: A case of ideal free distribution. Ardea 74: 105-109.

Göransson G., Schantz von T., Fröberg I., Helgée A. \& Wittzell H. 1990. Male characteristics, viability and harem size in the pheasant, Phasianus colchicus. Animal Behaviour 40: 89-104.

Hamilton W.D. \& ZuK M. 1982. Heritable true fitness and bright birds: a role for parasites. Science 218: 384-387.

Hasselquist D., Marsh J.A., Sherman P.W. \& Wingfield J.C. 1999. Is avian immunocompetence suppressed by testosterone? Behavioral Ecology and Sociobiology 45: 167-175.

HASSElquist D., Wasson M.F. \& WinKLER D.W. 2001. Humoral immunocompetence predicts date of egg-laying and reflects female quality in tree swallows. Behavioral Ecology 12: 93-97. 
Hatchwell B.J., Wood M.J., Anwar M., Chamberlain D.E. \& Perrins C.M. 2001. The haematozoan parasites of common blackbirds Turdus merula: associations with host condition. Ibis 143: 420-426.

HiLl G.E. 1990. Female house finches prefer colourful males: sexual selection for a conditiondependent trait. Animal Behaviour 38: 563-572.

HiLl G.E. 1992. Proximate basis of variation in carotenoid pigmentation in male house finches. Auk 109: 1-12.

HiLL G.E. 1996. Redness as a measure of the production cost of ornamental coloration. Ethology Ecology \& Evolution 8: 156-175.

HiLl G.E. 1998. An easy, inexpensive means to quantify plumage coloration. Journal of Field Ornithology 69: 353-363.

HiLl G.E. 1999. Is there an immunological cost to carotenoid-based ornamental coloration? The American Naturalist 154: 589-595.

Hill G.E. \& Montgomerie R. 1994. Plumage colour signals nutritional condition in the house finch. Proceedings of the Royal Society of London (B) 258: 47-52.

Hill G.E., Montgomerie R., Inouye C.Y. \& Dales J. 1994. Influence of dietary carotenoids on plasma colour in the house finch: intra- and intersexual variation. Functional Ecology 8 : 343-350.

Hillgarth N. \& Wingfield J.C. 1997. Parasite-mediated sexual selection: endocrine aspects, pp. 78-104. In: Clayton D.H. \& Moore J., Edits. Host-parasite evolution. General principles and avian models. Oxford: Oxford University Press.

Houde A.E. \& ToRio A.J. 1992. Effect of parasitic infection on male color pattern and female choice in guppies. Behavioral Ecology 3: 346-351.

IWASA Y., Pomiankowski A. \& NeE S. 1991. The evolution of costly mate preferences II. The "handicap" principle. Evolution 45: 1431-1442.

KLASING K.C. 1988. Influence of acute starvation or acute excess intake on immunocompetence of broiler chicks. Poultry Science 67: 626-634.

KLASING K.C. 1998. Nutritional modulation of resistance to infectious diseases. Poultry Science 77: $1119-1125$.

Kodric-Brown A. 1989. Dietary carotenoids and male mating success in the guppy: an environmental component to female choice. Behavioral Ecology and Sociobiology 25: 393401.

Koubek P. \& Hrabe V. 1984. Estimating the age of male Phasianus colchicus by bone histology and spur length. Folia Zoologica 33: 303-313.

Light Source 1994. Colortron user manual. San Rafael, California, USA: Light Source Inc.

LOChMiller R.L., Vestey M.R. \& BOREN J.C. 1993. Relationship between protein nutritional status and immunocompetence in northern bobwhite chicks. Auk 110: 503-510.

LozANo G.A. 1994. Carotenoids, parasites, and sexual selection. Oikos 70: 309-311.

LozANo G.A. 2001. Carotenoids, immunity, and sexual selection: comparing apples and oranges. The American Naturalist 158: 200-203.

Mateos C. 1998. Sexual selection in the ring-necked pheasant: a review. Ethology Ecology \& Evolution 10: 313-332.

Mateos C. \& CARranza J. 1995. Female choice for morphological features of male ring-necked pheasants. Animal Behaviour 49: 737-748.

Mateos C. \& CARRAnZA J. 1996. On the intersexual selection for spurs in the ring-necked pheasant. Behavioral Ecology 7: 362-369.

McGraW K.J. \& Hill G.E. 2000. Differential effects of endoparasitism on the expression of carotenoid- and melanin-based ornamental coloration. Proceedings of the Royal Society of London (B) 267: 1525-1531.

Nowicki S., Hasselquist D., Bensch S. \& Peters S. 2000. Nestling growth and song repertoire size in great reed warblers: evidence for song learning as an indicator mechanism in mate choice. Proceedings of the Royal Society of London (B) 267: 2419-2424.

Ohlsson T., Smith H.G., RÅBERG L. \& HAssElQuist D. 2002. Early nutrition, sexual ornaments and immunocompetence in pheasants. Proceedings of the Royal Society of London (B) 269: 21-27. 
Olsson N. 1954. Våra fjäderfän. Halmstad: LTs Förlag.

PAPESChI A., Briganti F. \& Dessì-Fulgheri F. 2000. Winter androgen levels and wattle size in male common pheasants. The Condor 102: 193-197.

RALPH C.L. 1969. The control of color in birds. American Zoologist 9: 521-530.

RidLeY, O.M.W. \& HiLl, D.A. 1987. Social organization in the pheasant (Phasianus colchicus): harem formation, mate selection and the role of mate guarding. Journal of Zoology, London 211: 619-630.

Rintamäki P.T., Höglund J., Karvonen E., Alatalo R.V., BJörklund N., Lundberg A., Rätti O. \& Vouti J. 2000. Combs and sexual selection in black grouse (Tetrao tetrix). Behavioral Ecology 11: 465-471.

RufF M.D., ReID W.M. \& Johnson J.K. 1974. Lowered blood carotenoid levels in chickens infected with coccidia. Poultry Science 53: 1801-1809.

Saino N., Calza S. \& Møller A.P. 1997. Immunocompetence of nestling barn swallows in relation to brood size and parental effort. Journal of Animal Ecology 66: 827-836.

Schantz von T., Bensch S., Grahn M., Hasselouist D. \& Wittzell H. 1999. Good genes, oxidative stress and condition-dependent sexual signals. Proceedings of the Royal Society of London (B) 266: 1-12.

Schantz von T., Göransson G., Andersson G., Fröberg I., Grahn M., Helgée A. \& Wittzell H. 1989. Female choice selects for a viability-based trait in pheasants. Nature 337: 166169.

SchantZ von T., Göransson G., Grahn M. \& WitTZell H. 1996. MHC genotype and male ornamentation: genetic evidence for the Hamilton-Zuk model. Proceedings of the Royal Society of London (B) 264: 265-271.

SchantZ vON T., Grahn M. \& Göransson G. 1994. Intersexual selection and reproductive success in the pheasant Phasianus colchicus. The American Naturalist 144: 510-527.

SHYKoff J.A. \& WIDMER A. 1996. Parasites and carotenoid-based signal intensity: how general should the relationship be? Naturwissenschaften 83: 113-121.

Sklan D., Melamed D. \& Friedman A. 1994. The effect of varying levels of dietary vitamin A on immune response in the chick. Poultry Science 73: 843-847.

Svensson E., RÅberg L., КосH C. \& Hasselouist D. 1998. Energetic stress, immunosuppression and the costs of an antibody response. Functional Ecology 12: 912-919.

TABER R.D. 1949. Observations on the breeding behavior of the ring-necked pheasant. The Condor 51: 153-175.

Veiga J.P. \& Puerta M. 1996. Nutritional constraints determine the expression of a sexual trait in the house sparrow, Passer domesticus. Proceedings of the Royal Society of London (B) 263: 229-234.

WeSTNEAT D.F. \& BiRKHEAD T.R. 1998. Alternative hypothesis linking the immune system and mate choice for good genes. Proceedings of the Royal Society of London (B) 265: 10651073.

WILKINSON L. 1987. SYSTAT. The system for statistics. Evanston, IL: Systat Inc.

ZAHAVI A. 1975. Mate selection - a selection for a handicap. Journal of Theoretical Biology 53: 205-214.

ZAHAVI A. 1977. The cost of honesty (further remarks on the handicap principle). Journal of Theoretical Biology 67: 603-605. 